\title{
Preparation of highly activated natural killer cells for advanced lung cancer therapy
}

This article was published in the following Dove Press journal: OncoTargets and Therapy

\author{
Silun Xie \\ Zhenyi $\mathrm{Wu}^{\prime}$ \\ Lizhi Niu ${ }^{2}$ \\ Jibing Chen ${ }^{3}$ \\ Yunkun $\mathrm{Ma}^{\prime}$ \\ Mingjie Zhang' \\ 'Research and Development \\ Department, HANK Bioengineering Co., \\ Ltd, Shenzhen, People's Republic of \\ China; ${ }^{2}$ Department of Oncology, Fuda \\ Cancer Hospital, Jinan University, \\ Guangzhou, People's Republic of China; \\ ${ }^{3}$ Department of Central Laboratory, Fuda \\ Cancer Hospital, Jinan University, \\ Guangzhou, People's Republic of China
}

Correspondence: Mingjie Zhang Research and Development Department, HANK Bioengineering Co., Ltd, Building I I9-5F, 72 Guowei Road, Shenzhen 5 18004, People's Republic of China Tel +8613923852418

Email ming.zhang@hankbio.org
Background: Natural killer (NK) cells can be used as an adoptive immunotherapy to treat cancer patients.

Purpose: In this study, we evaluated the efficacy of highly activated NK (HANK) cell immunotherapy in patients with advanced lung cancer.

Patients and methods: Between March 2016 and September 2017, we enrolled 13 patients who met the enrollment criteria. Donor peripheral blood monocytes were isolated from patients and the NK cells were expanded. After 12 days of culture, the cells were collected and infused intravenously on days 13 to 15 . The enrolled patients received at least one course including three times of infusions. The lymphocyte subsets, cytokine production, and the expression of carcinoembryonic antigen (CEA) and thymidine kinase 1 (TK1) were measured before treatment and after the last infusion.

Results: No side effects were observed. After a three-month follow-up, the percentage of patients who achieved stable disease and progressive disease was $84.6 \%$ and $15.4 \%$. Moreover, the level of IFN- $\gamma$ was significantly higher after treatment and the level of CEA decreased substantially. The overall immune function of the patients who received the NK cell therapy remained stable.

Conclusion: This is the first study to describe the efficacy of NK cell therapy of patients with advanced lung cancer. These clinical observations demonstrated that NK cell is safe and efficient for advanced lung cancer therapy.

Keywords: adoptive immunotherapy, highly activated natural killer cells, immune function, lung cancer

\section{Introduction}

Lung carcinoma is the most common type of cancer and the leading cause of cancer mortality in the People's Republic of China. ${ }^{1}$ Lung cancer includes nonsmall cell lung cancer (NSCLC) and small cell lung cancer, of which NSCLC accounts for approximately $80 \%$ and is defined as the most dangerous and common malignant cancer. $^{2,3}$ In addition, approximately $70 \%$ of patients with NSCLC are diagnosed at an advanced stage ${ }^{4}$ and the 5-year survival rate is only $16.8 \% .^{5}$ Surgery and chemotherapy are the standard therapies used to treat patients with NSCLC; however, they are insufficient to manage patients with advanced lung cancer due to a poor prognosis. ${ }^{6,7}$ Moreover, severe toxicity is exhibited following chemotherapy. Although biological therapy is an attractive alternative method for clinical treatment, variable therapeutic effects have been reported due to individual differences. Thus, the suppression of tumor cell proliferation in a complicated microenvironment remains a problem for researchers. Recently, progress in the field of adoptive 
immunotherapy has shown increased potential for the treatment of advanced lung cancer patients. ${ }^{8-10}$ However, a safe and efficient immunotherapy regimen is still required.

Natural killer (NK) cells are a critical component of the innate immune system and are characterized by their rapid response to and strong cytotoxicity against virusinfected or malignant cells without presensitization or restriction by major histocompatibility class I (MHC-I) molecules. $^{11-13}$ NK cells identify their target cells through a set of activating and inhibitory receptors. Then, NK cells recognize self MHC-I molecules that are expressed on normal cells but downregulated by infected or transformed cells, which is termed the "missing-self" model. ${ }^{14}$ When target cells exhibit decreased self MHC-I molecule expression or when the activating signals (activating receptors on NK cells and their corresponding ligands on tumor cells) dominate over the balance of inhibitory signals (inhibitory receptors on NK cells and their ligands on tumor cells), NK cell

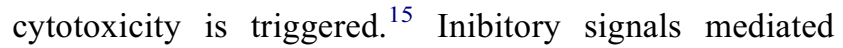
by killer cell immunoglobulin-like receptors and $\mathrm{NK}$ group 2A (NKG2A) on NK cells interact with MHCI molecules that are expressed on target cells. By comparison, various activating receptors like NK group 2D (NKG2D) and the natural cytotoxicity receptors (NCRs), including NKp30, NKp44, and NKp46, on NK cells provide positive signals when activated. ${ }^{16,17}$

NK cells are innate lymphocytes that are part of the first line of defense against tumor cells. In addition, NK cells can recognize and kill tumor cells without the requirement of prior antigen exposure. Recent studies have investigated the potential for NK cells to provide therapeutic benefit in patients with advanced lung cancer. ${ }^{18-21}$ Tumor cells can escape immune surveillance by downregulating the level of MHC molecule expression that releases NK cells from inhibition and initiates antitumor activities. ${ }^{22}$ With increased knowledge into NK cell function, adoptive NK cell therapy has been applied as a clinical treatment for advanced cancer patients, including lung cancer. ${ }^{23-27}$

To enhance the immune function of lung cancer patients, we isolated NK cells from patients themselves as adoptive immunotherapy. We developed the method to expand the NK cell number by a100-fold in 2 weeks with purity level $\geq 80 \%$, and the expression level of the activating receptor increased almost 200 -fold. ${ }^{28}$ We also reported a case in which an advanced ovarian cancer patient received highly activated NK (HANK) cells cultured and proliferated ex vivo by this approach and had a good response. ${ }^{29}$ Therefore, we adopted HANK cells to treat lung cancer patients in the clinical trial.

In this study, we assessed the clinical effect of HANK cell therapy in patients with advanced lung cancer, as a potential novel therapeutic regimen.

\section{Materials and methods Ethics}

This clinical trial was approved by the Guangzhou Fuda Cancer Hospital ethics committee. In accordance with the Declaration of Helsinki, written informed consent was obtained from each participant.

\section{Patient eligibility}

Patients were enrolled in the present study based on the following criteria: 1) life expectancy $>3$ months; 2) age $>18$ years; 3 ) Karnofsky performance status $>60$; 4) pathological or radiographic confirmation of stage III-IV lung cancer; 5) no serious abnormalities in liver, lung, and kidney function; 6) no high blood pressure, acute or chronic infection, or severe heart disease; 7) no HIV, HTLV-1, syphilis, tuberculosis, or parasitic infections; and 8) the absence of level 3 hypertension, severe coronary disease, myelosuppression, and autoimmune diseases.

\section{Preparation of HANK cells}

HANK cells were prepared under good manufacturing practice conditions using clinical-grade reagents. The human NK cell in vitro culture kit (HAHK Bioengineering Co. Ltd, Shenzhen, People's Republic of China) was used to costimulate expansion and activation of NK cells in the peripheral blood mononuclear cells (PBMCs) according to the manufacturer's instructions. Briefly, collect approximately $50 \mathrm{~mL}$ of peripheral blood from the patient. Transfer the blood to a $50-\mathrm{mL}$ conical tube and centrifuge at $600 \times \mathrm{g}$ for $15 \mathrm{~min}$. Collect the plasma in the supernatant in a $50-\mathrm{mL}$ conical tube. Add an equal volume of saline to the blood cells in the bottom, and resuspend the cells for lymphocyte separation. Transfer the plasma tube to a $56{ }^{\circ} \mathrm{C}$ water bath for $30 \mathrm{~min}$, then stand on the bench top until the tube temperature is below $37^{\circ} \mathrm{C}$, centrifuge at $400 \times \mathrm{g}$ for $10 \mathrm{~min}$, and transfer the supernatant into a new $50-\mathrm{mL}$ conical tube and store at $4{ }^{\circ} \mathrm{C}$ for further applications. The plasma tube stored at $4{ }^{\circ} \mathrm{C}$ for more than $12 \mathrm{~h}$ should be centrifuged again and only the supernatant used. Transfer $20 \mathrm{~mL}$ human lymphocyte separation solution (Haoyang Biological Manufacture Co., Ltd, 
Tianjin, People's Republic of China) into two 50-mL conical tubes, respectively. Carefully lay equal volumes of the blood cell suspension onto the lymphocyte separation solution in two $50-\mathrm{mL}$ conical tubes, centrifuge at $600 \times \mathrm{g}$ for $15 \mathrm{~min}$, transfer the lymphocytes into the middle layer into a $50-\mathrm{mL}$ conical tube, and wash twice with saline. The total cell number is counted.

NK cell culture media consist of $1 \mathrm{~L}$ of X-Vivo15 serumfree medium (Lonza, Walkersville, MD, USA) and one tube of HK-002 (5\% for initial $200 \mathrm{~mL}$ of medium, then reduce to $1-2 \%)$. A tube of HK-001 contains membrane chimeric active cellular factors. One tube of HK-001 is good for $4 \times 10^{7}$ lymphocyte initial culture. Calculate the number of HK-001 tubes needed according to the lymphocyte numbers. Take HK-001 out of the liquid nitrogen or $-80{ }^{\circ} \mathrm{C}$ freezer, and immediately put into a $37{ }^{\circ} \mathrm{C}$ water bath to recover. Then centrifuge at $350 \times \mathrm{g}$ for $5 \mathrm{~min}$, and remove the supernatant. Wash the precipitate twice with saline. Resuspend the precipitate with about $3 \mathrm{~mL} \mathrm{NK}$ cell culture medium.

The NK cells were cultured as follows. On day 1, mix $4 \times 10^{7}$ lymphocytes, $50 \mathrm{~mL} \mathrm{NK}$ cell culture medium, and one tube of recovered HK-001 in a T175 culture flask (Corning Incorporated, Corning, NY, USA) and incubate at $37^{\circ} \mathrm{C}$ with $5 \% \mathrm{CO}_{2}$. On day 3 , add $30 \mathrm{~mL} \mathrm{NK}$ cell culture medium to the T175 flask. On day 5, add $60 \mathrm{~mL}$ NK cell culture medium to the T175 flask and adjust the cell concentration to $1 \times 10^{6} / \mathrm{mL}$. On day 6 , add $60 \mathrm{~mL}$ NK cell culture medium to the T175 flask and, adjust the cell concentration to $1 \times 10^{6} / \mathrm{mL}$. On day 7 , add $50 \mathrm{~mL}$ NK cell culture medium (1-2\% plasma concentration) to the T175 flask. Count the cell number. If the total cell number is $>6 \times 10^{7}$ cells, add a tube of recovered HK-
001 ; or if the total cell number is $3 \sim 6 \times 10^{7}$ cells, add a tube of recovered HK-001 1 day later. Perform the first sterility test. On day 8 , transfer the total culture from the T175 flask to the 2-L cell culture bag (Haoyang Biological Manufacture Co., Ltd). Add $200 \mathrm{~mL} \mathrm{NK}$ cell culture medium to the cell culture bag. On days 9, 10, and 11, add $150 \mathrm{~mL} \mathrm{NK}$ cell culture medium to the cell culture bag each day. On day 12, add $350 \mathrm{~mL}$ NK cell culture medium to the cell culture bag. Perform the quality control tests including cell viability, NK cell purity, and endotoxin. On day 13, harvest the HANK cells. Count the total cell number (should be around $1 \times 10^{10}$ cells). Collect the cultures into $450-\mathrm{mL}$ conical centrifuge tubes. Precipitate cells and wash the cells once with saline. Adjust the cell concentration to $2 \times 10^{7} / \mathrm{mL}$ with cell infusion solution $(400 \mathrm{~mL}$ saline with $1 \%$ human serum albumin and $6 \mathrm{~mL}$ HK-003). A sample of $3-5 \times 10^{9}$ HANK cells was harvested into blood transfusion bags each day for infusion at a concentration of $2 \times 10^{7} / \mathrm{mL}$. The release tests were performed on each bag of cells. The process of HANK cell preparation is shown in Figure 1.

NK cells were stained with anti-CD3-APC-H7, anti-CD16Alexa Fluor700, anti-CD56-PE, anti-NKG2D-PerCP-Cy5.5, anti-NKG2A-PE-Cy7, anti-NKp30-APC, anti-NKp44-PE, and anti-NKp46-BV786 (BD Biosciences, San Jose, CA, USA). Then, the cells were washed with fluorescent activated cell-sorting buffer (0.2\% BSA) (Hyclone), fixed with $1 \%$ paraformaldehyde (Sigma-Aldrich Co., St Louis, MO, USA), and analyzed on the FACSCanto ${ }^{\mathrm{TM}}$ II (BD, Franklin Lakes, NJ, USA). Data analysis was performed using FlowJo software (Treestar). Cells were gated on $\mathrm{CD} 56^{+} \mathrm{CD}^{-}$events (NK cells) and then analyzed for the expression of inhibitory and

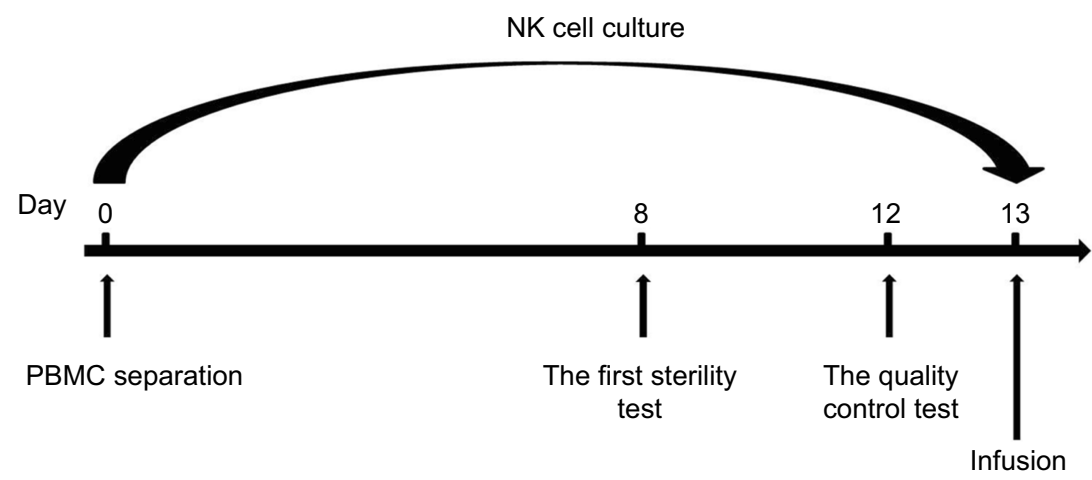

Figure I NK expansion process. PBMCs were obtained from peripheral blood (approximately $50 \mathrm{~mL}$ ) of each cancer patient. The plasma was prepared, and the lymphocytes were separated using human lymphocyte separation solution. The lymphocytes were resuspended in NK cell culture medium and cultured. For the first week, the cells were cultured in a TI75 culture flask. From day 8 , the cells were cultured in a 2-L cell culture bag. The first sterility test was performed on day 8 , while the quality control (cell viability $\geq 80 \%$, NK cell purity $\geq 80 \%$, endotoxin $\leq I \mathrm{EU} / \mathrm{mL}$, and bacteria, fungi, and mycoplasma culture-negative) and sterility tests were performed on day 12 . On day 13, approximately 3-5 $\times 10^{9}$ HANK cells were harvested into a blood transfusion bags each day for infusion at a concentration of approximately $2 \times 10^{7} / \mathrm{mL}$.

Abbreviations: NK, natural killer; PBMC, peripheral blood mononuclear cell; HANK, highly activated natural killer. 
activating surface receptors. The assessment was performed in freshly isolated peripheral blood mononuclear cells (PBMCs) on day 0 as well as expanded and activated NK cells on day 12 .

\section{Therapeutic procedure}

Enrolled patients stopped pretreatment before HANK cell therapy. All enrolled patients received at least one course of treatment (each course included three infusions, the length of time for each infusion was within $30 \mathrm{~min}$ ). No more than three courses of treatment were received monthly. Each course with three infusions was delivered consecutively over 3 days.

\section{Evaluation of safety and clinical efficacy Adverse effect observation}

The most common adverse reactions recorded include local (eg, pain and retroperitoneal errhysis) and systemic (eg, chills, fatigue, and fever) reactions. Blood toxicity was measured by the white blood cell count (reference: $3.5-9.5 \times 10^{9}$ cells $/ \mathrm{L}$ ) and the hemoglobin level (reference: $130-175 \mathrm{~g} / \mathrm{L}$ ). Hepatic toxicity was measured by aspartate transaminase (reference: $15-40 \mathrm{U} / \mathrm{L}$ ) and alanine aminotransferase ALT (reference: 9-50 U/L). Renal toxicity was measured by creatinine (reference: $57-97 \mu \mathrm{mol} / \mathrm{L}$ ) level. All of these indexes were measured 14 days before and after HANK cell infusion as a detection index to evaluate adverse effects.

\section{Detection of immune function}

Lymphocyte subsets were detected by flow cytometry (FACSCanto $^{\mathrm{TM}}$ II; BD). Peripheral blood $(2 \mathrm{~mL})$ was drawn to assess the level of immune function before and after the HANK cell infusion. The number of $\mathrm{CD}^{+} \mathrm{CD}^{+}$(reference range: 125-1312 cells $/ \mu \mathrm{L}$ ), $\mathrm{CD}^{+} \mathrm{CD}^{+}$(reference range: 441-2156 cells $\mu \mathrm{L}$ ), $\mathrm{CD}^{-}{ }^{-} \mathrm{CD} 16^{+} \mathrm{CD}^{+} 6^{+}$(reference range: $95-640$ cells $/ \mu \mathrm{L}$ ), total $\mathrm{CD}^{+}$(reference range: 603-2990 cells $/ \mu \mathrm{L}$ ), and $\mathrm{CD}^{-}{ }^{-} \mathrm{CD} 19^{+}$(reference range: $107-698$ cells $/ \mu \mathrm{L}$ ) cells was detected by the BD Multitest 6-color TBNK Reagent (BD Biosciences). The BD Cytometric Bead Array Human Th1/Th2 Cytokine Kit II (No. 551,809; BD) was used to detect the expression of IL-2 (reference range: $8-12.5 \mathrm{pg} / \mathrm{mL}$ ), IL-4 (reference range: $3.5-6$ $\mathrm{pg} / \mathrm{mL}$ ), IL-6 (reference range: $2.7-8.5 \mathrm{pg} / \mathrm{mL}$ ), IL-10 (reference range: $1.8-4 \mathrm{pg} / \mathrm{mL}$ ), tumor necrosis factor- $\beta$ (reference range: $1.7-2.5 \mathrm{pg} / \mathrm{mL}$ ), and interferon- $\gamma$ (reference range: $1.5-4 \mathrm{pg} / \mathrm{mL}$ ). These factors are inhibited by tumor proliferation, and the level of these cytokines is indicative of the potency of the antitumor response elicited by the immune system. ${ }^{30}$

\section{Tumor biomarkers}

The level of carcinoembryonic antigen (CEA) and thymidine kinase 1 (TK1) was measured. TK1 is associated with DNA synthesis related to cellular proliferation and is used to monitor the effect of tumor therapy, prognosis, and followup. In addition to TK1, CEA is a tumor-associated antigen that is an important marker for lung cancer. Peripheral blood (5-6 mL) was collected for the detection of TK1 and CEA. The TK1 analytical reagent kit and CIS-2 series chemiluminescence digital imaging analyzer (Sino-Swed Tong Kang Bio-Tech Co. Ltd., Shenzhen, People's Republic of China) were used to detect the TK1 level (normal range: 0-2.0 pM) before and after the HANK cell immunotherapy. The expression level of CEA was detected by a chemiluminescent immunoassay.

\section{Computed tomography imaging scan}

Changes in computed tomography tumor imaging were monitored to evaluate the curative effect of the treatment according to the evaluation standards published by the World Health Organization. ${ }^{31}$ According to the degree of change in the largest transverse diameter, the therapeutic effect is categorized as: 1) complete response (CR), in which there is a disappearance of the arterial enhancement imaging of all target lesions; 2) partial response (PR), in which there is a total reduction in the diameter of the target lesions $>30 \%$; 3) stable disease, in which tumor regression fails to reach PR or tumor progression fails to reach progressive disease; and 4) progressive disease, a total progression of the tumor diameter $>20 \%$. To accurately observe the therapeutic effects of HANK cell therapy, the total area of all tumors before and after treatment was compared. Any curative effect must be maintained for more than 4 weeks, with $\mathrm{CR}+\mathrm{PR}$ representing the effective rate (RR).

\section{Statistical analysis}

SPSS version 13.0 (SPSS Inc., Chicago, IL, USA) was used for the statistical analyses, and the results were expressed as the mean and SD values. GraphPad Prism 5 (GraphPad Software Inc., La Jolla, CA, USA) was used to plot graphs. The two groups (immune function and tumor markers) were compared using Wilcoxon signed-rank tests. All statistical tests were two-sided, and differences were considered significant at $p<0.05$. 


\section{Results}

\section{Patient characteristics}

From March 2016 to September 2017, a total of 13 patients (eight males, five females) with a median age of 57.3 years (range: $37-84$ years) and a diagnosis of adenocarcinoma $(n=12)$ or squamous cell carcinoma $(n=1)$ were enrolled in the study. Among these patients, stage IV, III, and II was detected in 10, 2, and 1 patient, respectively (Table 1).

\section{Treatment safety}

Before HANK cell therapy, all other therapies were stopped. The detailed pretreatment data are shown in Table 2. During all infusions, the patients did not report a cold chill, fever, or any other discomfort. There was no case of queasiness or vomiting. After 14 days of HANK cell infusion, the white blood cell count and the aspartate transaminase, alanine aminotransferase, hemoglobin, and creatinine levels were not significantly different from those before treatment $(p>0.05)$ (Table 3$)$. It was demonstrated that blood function, liver function, and renal function remained at a normal level.

\section{NK cell purity before and after in vitro expansion and activation}

Prior to NK cell expansion, the median percentage of the $\mathrm{CD}^{-} \mathrm{CD}^{+} 6^{+}$population in $\mathrm{PBMC}$ was $13.4 \%$ (range: 9.4-16.8\%). Following expansion, the proportion of viable cells exceeded $92 \%$ without any bacterial, fungal, or mycoplasma contamination (endotoxin level $<1 \mathrm{EU}$ ). The median proportion of $\mathrm{CD}^{-} \mathrm{CD} 56^{+}$cells was $88.1 \%$ (range: $81.3-94.9 \%$ ). The representative results are presented in Figure 2.

We also examined the expression rates of various activating and inhibitory receptors on the NK cell surface. The results show that there is a significant increase in the expression of activating receptors after culture compared to those on PBMC before expansion (Figure 3). For instance, $\mathrm{NKG} 2 \mathrm{D} / \mathrm{CD} 56^{+} \mathrm{NK}$ cells increase from $24 \%$ in PBMCs to $95 \%$ after 12 days of NK cell culture. Similarly, NKp30/CD56 ${ }^{+}$NK cells, NKp44/CD56 ${ }^{+}$NK cells, and $\mathrm{NKp} 46 / \mathrm{CD}^{2} 6^{+} \mathrm{NK}$ cells were increased from $22 \%$, $0.5 \%$, and $62 \%$ to $65 \%, 66 \%$, and $78 \%$, respectively. Moreover, expansion and activation of NK cells had no influence on $\mathrm{NKG} 2 \mathrm{~A} / \mathrm{CD}^{+} 6^{+} \mathrm{NK}$ cells with a stable change from $14 \%$ on day 0 to $12 \%$ on day 12 .

\section{Immune function changes in patients with advanced lung cancer following HANK cell therapy}

The level of interferon- $\gamma$ was significantly higher after treatment $(p<0.05)$. In addition, the lymphocyte subset number remained stable (Table 4 ). No change was observed regarding the level of cytokines, including IL-2, IL-4, IL6, IL-10, and tumor necrosis factor- $\beta(p>0.05)$ (Table 5).

\section{Changes in tumor biomarker expression}

The level of CEA significantly decreased following HANK cell adoptive immunotherapy $(p<0.05)$. The mean TK1 value before HANK cell immunotherapy was 2.08 $\pm 4.35 \mathrm{pmol} / \mathrm{L}$ and increased to $2.7 \pm 5.78 \mathrm{pmol} / \mathrm{L}$ after the

Table I Patient characteristics

\begin{tabular}{|c|c|c|c|c|c|}
\hline No. & Age (years) & Gender & Histology stage & Smoking status & Metastasis \\
\hline I & 84 & $M$ & A IV & $\mathrm{N}$ & Bone \\
\hline 2 & 37 & $M$ & A IV & $\mathrm{N}$ & Bone \\
\hline 3 & 57 & $M$ & A II a & $\mathrm{N}$ & No \\
\hline 4 & 48 & $M$ & A IV & $\mathrm{N}$ & Liver \\
\hline 5 & 55 & $\mathrm{~F}$ & A IV & $\mathrm{N}$ & Bone \\
\hline 6 & 57 & $\mathrm{~F}$ & A IV & $\mathrm{N}$ & Lung \\
\hline 7 & 54 & $\mathrm{~F}$ & SCC IV & $\mathrm{N}$ & Bone \\
\hline 8 & 82 & $M$ & A IIIb & $\mathrm{N}$ & No \\
\hline 9 & 45 & $M$ & A III & $\mathrm{N}$ & Bone, liver \\
\hline 10 & 62 & $\mathrm{~F}$ & A IV & $\mathrm{N}$ & Bone \\
\hline II & 60 & $\mathrm{~F}$ & A IV & $\mathrm{N}$ & Lung \\
\hline 12 & 37 & $M$ & A IV & 10 years, 5 cigarettes a day & Bone, lung \\
\hline 13 & 67 & $M$ & A IV & $\mathrm{N}$ & Bone, lung \\
\hline
\end{tabular}

Abbreviations: M, male; F, female; A, adenocarcinoma; SCC, squamous cell carcinoma; N, no smoking history. 
Table 2 Pretreatment data

\begin{tabular}{|c|c|c|c|}
\hline No. & Size of primary lesion $(\mathrm{cm})$ & Therapeutic regimen & Result \\
\hline I & $5.2 \times 5.0$ & Mar and Apr 2016: cryoablation+iodine seed implantation & SD \\
\hline 2 & $5.8 \times 7.7$ & $\begin{array}{l}\text { Oct 2015: radiotherapy } \\
\text { Oct 2015-Apr 2016: chemotherapy } \\
\text { May and Jun 2016: cryoablation+iodine seed implantation }\end{array}$ & SD \\
\hline 3 & $1.8 \times 1.6$ & $\begin{array}{l}\text { Oct 2015-Oct 2016: targeted therapy } \\
\text { Jun 2017: cryoablation+iodine seed implantation }\end{array}$ & PD \\
\hline 4 & $3.9 \times 2.8$ & $\begin{array}{l}\text { Dec 2014-Mar 2016: chemotherapy } \\
\text { May 2016: cryoablation+iodine seed implantation }\end{array}$ & PD \\
\hline 5 & $1.5 \times 1.6$ & Apr and Aug 2016: surgery+chemotherapy & SD \\
\hline 6 & $2.8 \times 1.8$ & $\begin{array}{l}\text { May 2015: cryoablation } \\
\text { Jun and Sep 2015: chemotherapy } \\
\text { Jan 2016: cryoablation }\end{array}$ & SD \\
\hline 7 & $2.5 \times 1.4$ & Jan 2016: chemotherapy & SD \\
\hline 8 & $4.4 \times 2.2$ & Jan 2016: cryoablation & SD \\
\hline 9 & $2.0 \times 1.7$ & Jun 2015: surgery & SD \\
\hline 10 & $1.4 \times 2.7$ & Nov 201 I so far: chemotherapy & SD \\
\hline II & $1.7 \times 1.3$ & $\begin{array}{l}\text { May 2015: surgery } \\
\text { Jan 2016: chemotherapy }\end{array}$ & SD \\
\hline 12 & $2.7 \times 2.9$ & Nov 2015: targeted therapy & SD \\
\hline 13 & $8.2 \times 5.6$ & $\begin{array}{l}\text { Jan and Mar } 2010 \text { so far: radiotherapy+chemotherapy } \\
\text { Aug 2016: cryoablation+chemotherapy }\end{array}$ & SD \\
\hline
\end{tabular}

Abbreviations: SD, stable disease; PD, progressive disease.

Table 3 Detection index of adverse effects

\begin{tabular}{|l|l|l|l|l|l|}
\hline & WBC $\left(1 \mathbf{0}^{9} / \mathbf{L}\right)$ & Hb $(\mathbf{g} / \mathbf{L})$ & AST $(\mathbf{U} / \mathbf{L})$ & ALT $(\mathbf{U} / \mathbf{L})$ & Cr $(\mu \mathrm{mol} / \mathbf{L})$ \\
\hline Before treatment & $6.95 \pm 1.74$ & $124.15 \pm 18.7$ & $26.77 \pm 23.49$ & $28.54 \pm 20.1$ & $56.38 \pm 12.95$ \\
After treatment & $6.37 \pm 2.53$ & $118 \pm 22.13$ & $18.46 \pm 6.66$ & $21.62 \pm 4.44$ & $49.54 \pm 12.2$ \\
$p$-value & 0.307 & 0.272 & 0.073 & 0.556 & 0.196 \\
\hline
\end{tabular}

Note: Values shown are the mean \pm SD. ${ }^{*} p<0.05$.

Abbreviations: WBC, white blood cell count; Hb, hemoglobin; AST, aspartate transaminase; ALT, alanine aminotransferase; Cr, creatinine.

last transfusion. Thus, there is no substantial change in the level of TK1 (Table 6).

\section{Clinical outcomes}

A total of 13 patients received different courses of autologous HANK cell infusion. After 3 months, 11 patients (84.6\%) experienced stable disease and 2 patients $(15.4 \%)$ experienced progressive disease according to the RECIST guidelines (Table 7).

\section{Discussion}

Lung cancer is reported to be a major cause of mortality and is associated with the highest incidence among all malignancies worldwide. ${ }^{32}$ Furthermore, the majority of patients are diagnosed with advanced or metastatic disease. ${ }^{33}$ Although chemotherapy and radiotherapy can be effective to some extent, the curative and beneficial effects of these treatments are severely limited. ${ }^{34,35}$

Adoptive immunotherapy has long been recognized as a promising novel approach for the treatment of solid tumors. ${ }^{36}$ As a part of the innate immune system, NK cells are highly related to the tumor microenvironment and mediate cytotoxic activity against tumor cells. ${ }^{37}$ Thus, the clinical application of NK cell adoptive immunotherapy as a potential treatment for patients with solid tumors has recently gained attention. ${ }^{38-40}$

A previous study has shown that NK cells can recognize and lyse cells lacking MHC-I molecules through their activating receptors like NKG2D, NKp46, NKp44, and NKp30. ${ }^{16,17}$ Hence, tumor cells are highly susceptible to NK cells due to their lack of MHC-I molecule expression. ${ }^{14}$ In addition, the balance between activating and inhibitory 
A

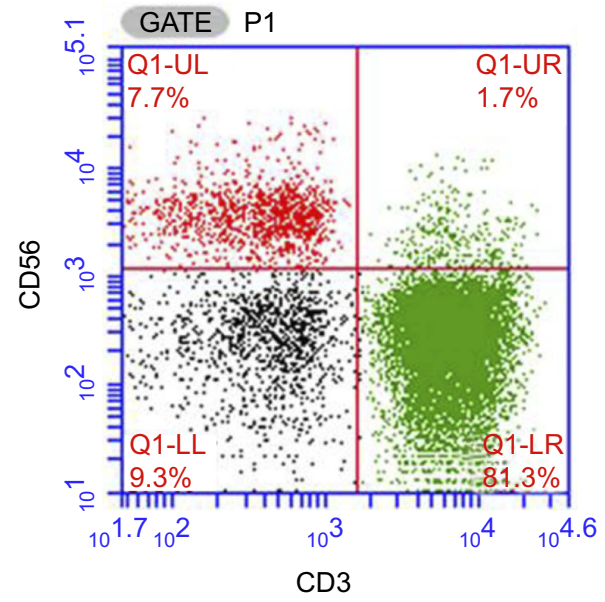

B

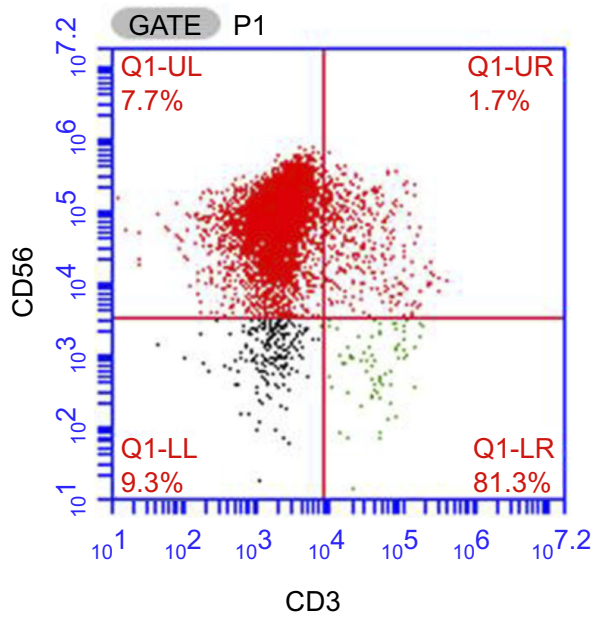

Figure 2 The $\mathrm{CD}^{-} \mathrm{CD} 56^{+} \mathrm{NK}$ cell proportion before and after in vitro expansion. (A) The proportion of NK cells before the expansion. (B) The proportion of NK cells after expansion on day 12.

Abbreviation: NK, natural killer.

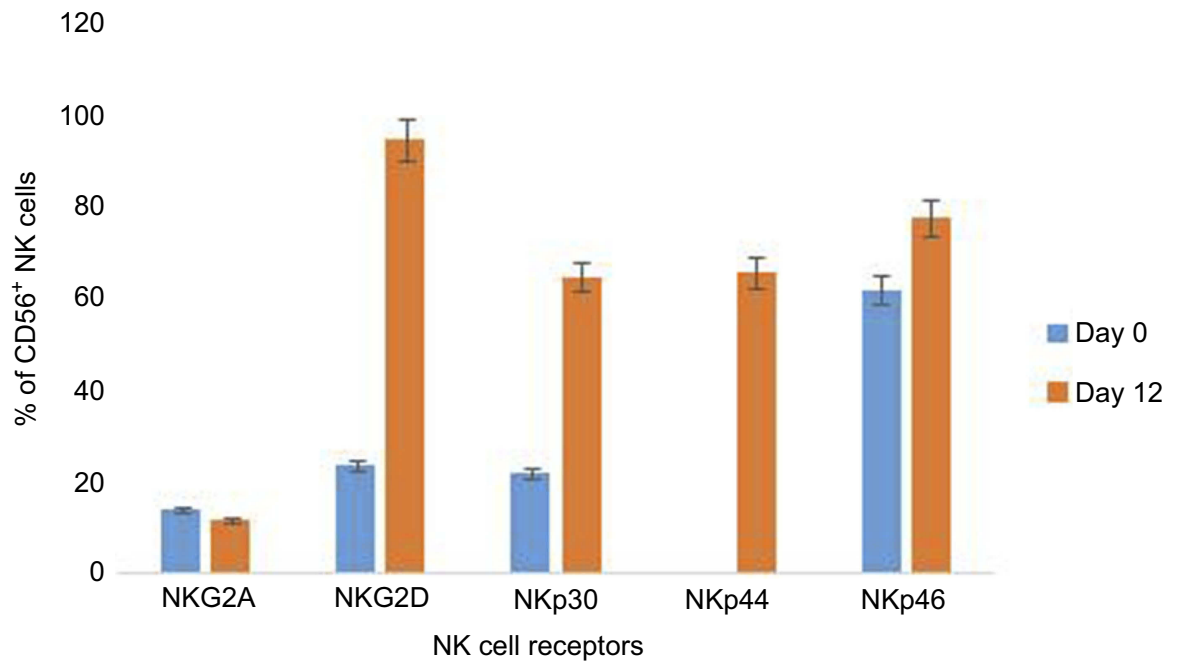

Figure 3 Effects of ex vivo expansion on expression of NK cells. NK cells were stained with conjugated antibodies like PE or APC, etc., against activating receptors such as NKG2D, NKp30, NKp44, and NKp46 or an inhibitory receptor such as NKG2A. Flow cytometry was performed after incubation. The presented data show the results from one donor. The error bars represent SDs, according equal weight to all three assays.

Abbreviations: NK, natural killer; NKG2, NK group 2.

receptor signaling on NK cells is crucial to NK cell functionality, including cytokine production, cytotoxicity mediated by NK cells such as perforin and granzyme, and antibodydependent cell-mediated cytotoxicity. ${ }^{4-46}$ Depending on the balance between the activating and inhibitory signals engaged by ligands expressed on tumor cells, NK cells are triggered to kill or ignore target cells. Data from recent studies indicate that in response to NK cell therapy, the expression of NK cell activating receptors like NKG2D increased, whereas the expression of inhibitory receptors did not, suggesting that NK cell therapy can activate NK cells in advanced cancer patients. ${ }^{23,47}$ However, the clinical application of NK cells has been limited by the low frequency of NK cells in peripheral blood (5-20\%). Moreover, the expansion of NK cells to abundant numbers in vitro also remains difficult.

A recent study reported that expansion of NK cells can be achieved by inducing proliferation in response to the presence of feeder cells, such as irradiated PBMC, Epstein-Barr virus-transformed lymphoblastoid cell lines, and gene-modified K562 cells, which act as artificial antigen-presenting cells. ${ }^{24,48-50}$ In particular, feeder 
Table 4 The number of lymphocytes isolated from lung cancer patients before and after highly activated natural killer cell immunotherapy

\begin{tabular}{|l|l|l|l|}
\hline Lymphocytes & $\begin{array}{l}\text { Before treat- } \\
\text { ment } \\
\text { (cells/ } \boldsymbol{\mu L} \text { ) }\end{array}$ & $\begin{array}{l}\text { After treat- } \\
\text { ment } \\
\text { (cells/ } \boldsymbol{\mu L} \text { ) }\end{array}$ & $\boldsymbol{p}$-value \\
\hline Total T cells & $754.5 \pm 391.858$ & $763.1 \pm 499.418$ & 0.807 \\
CD4 ${ }^{+}$T cells & $399.5 \pm 264.015$ & $424.7 \pm 321.786$ & 0.972 \\
CD8 $^{+}$T cells & $343.1 \pm 256.85$ & $379.7 \pm 311.261$ & 0.552 \\
B cells & $108.7 \pm 91.846$ & $115 \pm 92.022$ & 0.753 \\
Natural killer & $150.2 \pm 91.846$ & $198.9 \pm \mid 49.81$ & 0.064 \\
cells & & & \\
\hline
\end{tabular}

Table 5 The level of cytokines expressed in peripheral blood before and after highly activated natural killer cell immunotherapy

\begin{tabular}{|l|l|l|l|}
\hline Cytokine & $\begin{array}{l}\text { Before } \\
\text { treatment }\end{array}$ & $\begin{array}{l}\text { After } \\
\text { treatment }\end{array}$ & p-value \\
\hline IL-2 & $14.02 \pm 2.915$ & $14.48 \pm 2.5 \mathrm{I}$ & 0.345 \\
IL-4 & $10.36 \pm 2.485$ & $9.71 \pm 0.724$ & 0.463 \\
IL-6 & $22.98 \pm 9.26$ & $26.13 \pm 18.88$ & 0.972 \\
IL-10 & $8.79 \pm 1.349$ & $11.83 \pm 6.14$ & 0.101 \\
TNF- $\beta$ & $5.24 \pm 0.5$ & $5.28 \pm 0.64$ & 0.65 \\
IFN- $\gamma$ & $6.55 \pm 0.64$ & $7.79 \pm 2.25$ & $0.039 \triangle$ \\
\hline
\end{tabular}

Note: Values shown are the mean \pm SD. ${ }^{{ }} p<0.05$

Abbreviations: TNF, tumor necrosis factor; IFN, interferon.

Table 6 The level of CEA and TKI prior to and following highly activated natural killer cell adoptive immunotherapy

\begin{tabular}{|l|l|l|l|}
\hline Expression & $\begin{array}{l}\text { Before } \\
\text { treatment }\end{array}$ & $\begin{array}{l}\text { After } \\
\text { treatment }\end{array}$ & $\boldsymbol{p}$-value \\
\hline CEA $(\mathrm{ng} / \mathrm{ml})$ & $65.68 \pm 99.27$ & $31.63 \pm 62.2$ & $0.009 \triangle$ \\
TKI $(\mathrm{pmol} / \mathrm{L})$ & $2.08 \pm 4.35$ & $2.7 \pm 5.78$ & 0.382 \\
\hline
\end{tabular}

Note: Values shown are the mean \pm SD. ${ }^{\triangle} p<0.05$.

Abbreviations: CEA, carcinoembryonic antigen; TKI, thymidine kinase I.

cells based on genetically modified K562 cells that contain chimeric active cellular factors on $\mathrm{K} 562$ cell membranes produce a high quantity of NK cells. ${ }^{51,52}$ The human NK cell in vitro culture kit used in this study contains membrane chimeric cellular factors. However, a concern is that the in vitro expanded NK cells may reduce their cytotoxicity and persistence in vivo within several weeks. Ready to take fast action but a short persistence time are the advantage and disadvantage of adoptive NK cell therapy. Thus, repeated infusions are needed.

A series of studies have demonstrated that NK cell therapy is a promising therapeutic approach to advanced
Table 7 Clinical outcome of highly activated natural killer cell treatment after 3 months

\begin{tabular}{|c|c|c|}
\hline No. & Time of transfusions & Clinical outcome \\
\hline I & $\begin{array}{l}\text { Apr 2016: I course } \\
\text { Jun 2016: I course }\end{array}$ & SD \\
\hline 2 & $\begin{array}{l}\text { Aug 2016: I course } \\
\text { Oct 2016: I course }\end{array}$ & SD \\
\hline 3 & $\begin{array}{l}\text { Jul 2017: I course } \\
\text { Aug 20I7: } 2 \text { courses } \\
\text { Sep 2017: I course }\end{array}$ & PD \\
\hline 4 & Oct 2016: I course & PD \\
\hline 5 & $\begin{array}{l}\text { Sep 2016: I course } \\
\text { Oct 2016: } 3 \text { courses }\end{array}$ & SD \\
\hline 6 & $\begin{array}{l}\text { Jul 2016: I course } \\
\text { Aug 2016: } 2 \text { courses } \\
\text { Sep 2016: } 2 \text { courses } \\
\text { Oct 2016: } 2 \text { courses }\end{array}$ & SD \\
\hline 7 & $\begin{array}{l}\text { Nov 2016: I course } \\
\text { Dec 2016: } 2 \text { courses } \\
\text { Jan 2017: } 2 \text { courses } \\
\text { Feb 2017: I course }\end{array}$ & SD \\
\hline 8 & $\begin{array}{l}\text { Jul 2016: I course } \\
\text { Aug 2016: } 2 \text { courses } \\
\text { Sep 2016: } 2 \text { courses } \\
\text { Oct 2016: } 2 \text { courses }\end{array}$ & SD \\
\hline 9 & Mar 2016: I course & SD \\
\hline 10 & $\begin{array}{l}\text { Jul 2016: I course } \\
\text { Sep 2016: } 2 \text { courses } \\
\text { Oct 2016: } 2 \text { courses }\end{array}$ & SD \\
\hline 11 & $\begin{array}{l}\text { Sep 2016: I course } \\
\text { Oct 2016: I course }\end{array}$ & SD \\
\hline 12 & $\begin{array}{l}\text { Sep 2016: I course } \\
\text { Oct 2016: } 2 \text { courses }\end{array}$ & SD \\
\hline 13 & $\begin{array}{l}\text { Sep 2016: I course } \\
\text { Oct 2016: I course } \\
\text { Nov 2016: I course } \\
\text { Dec 2016: I course } \\
\text { Jan 2017: I course } \\
\text { Feb 2017: I course } \\
\text { Apr 2017: I course }\end{array}$ & SD \\
\hline
\end{tabular}

Abbreviations: SD, stable disease; PD, progressive disease.

lung cancer. Tonn et $\mathrm{al}^{53}$ observed that some encouraging responses in patients with advanced lung cancer after two infusions of natural killer cell line NK-92. Yang et $\mathrm{al}^{26}$ found that treatment of NK cell-rich lymphocytes combined with docetaxel in patients with advanced NSCLC was feasible without further toxicity or complication. Other regimens such as targeted therapy and percutaneous cryoablation combined with NK cell immunotherapy in advanced NSCLC patients also achieved satisfactory results. ${ }^{54,55}$ In addition, some 
clinical studies have been performed well in various tumors combined with chemotherapy or antibody. ${ }^{27,56}$ It is not only safe and feasible, but also a better immune response is achieved when NK cell therapy is applied in cancer patients. ${ }^{57,58}$

In summary, we have developed a practical, simple, safe, and economical NK cell expansion and activation procedure, which result in NK cells are with high quantity, high purity and high activity characterizations. Application of these NK cells for advanced lung cancer immunotherapy was safe and efficient, most of them remained in a stable condition. Although this NK cell therapy shows promise as a potential cancer treatment, further studies are needed to obtain additional improved curative effect.

\section{Disclosure}

The authors report no conflicts of interest in this work.

\section{References}

1. Chen W, Zheng R, Baade PD, et al. Cancer statistics in China, 2015. CA Cancer J Clin. 2016;66(2):115-132. doi:10.3322/caac.21338

2. Daga A, Ansari A, Patel S, Mirza S, Rawal R, Umrania V. Current drugs and drug targets in non-small cell lung cancer: limitations and opportunities. Asian Pac J Cancer Prev. 2015;16(10):4147-4156.

3. Miller KD, Siegel RL, Lin CC, et al. Cancer treatment and survivorship statistics, 2016. CA Cancer J Clin. 2016;66(4):271-289. doi: $10.3322 /$ caac. 21349

4. Molina JR, Yang P, Cassivi SD, Schild SE, Adjei AA. Non-small cell lung cancer: epidemiology, risk factors, treatment, and survivorship. Mayo Clin Proc. 2008;83(5):584-594. doi:10.4065/83.5.584

5. Cronin KA, Ries LA, Edwards BK. The surveillance, epidemiology, and end results (SEER) program of the national cancer institute. Cancer. 2014;120(Suppl 23):3755-3757. doi:10.1002/cncr.29049

6. Ahn SH, Han MS, Yoon JH, et al. Treatment of stage I non-small cell lung cancer with CyberKnife, image-guided robotic stereotactic radiosurgery. Oncol Rep. 2009;21(3):693-696.

7. Park S, Kim IR, Baek KK, et al. Prospective analysis of quality of life in elderly patients treated with adjuvant chemotherapy for non-small-cell lung cancer. Ann Oncol. 2013;24(6):1630-1639. doi:10.1093/annonc/mds649

8. Li R, Wang C, Liu L, et al. Autologous cytokine-induced killer cell immunotherapy in lung cancer: a phase II clinical study. Cancer Immunol Immunother. 2012;61(11):2125-2133. doi:10.1007/s00262$012-1260-2$

9. Zhang J, Zhu L, Du H, et al. Autologous cytokine-induced killer cell therapy in lung cancer patients: a retrospective study. Biomed Pharmacother. 2015;70:248-252. doi:10.1016/j.biopha.2014.12.025

10. Zhong R, Teng J, Han B, Zhong H. Dendritic cells combining with cytokine-induced killer cells synergize chemotherapy in patients with late-stage non-small cell lung cancer. Cancer Immunol Immunother. 2011;60(10):1497-1502. doi:10.1007/s00262-011-1060-0

11. Miller JS. The biology of natural killer cells in cancer, infection, and pregnancy. Exp Hematol. 2001;29(10):1157-1168.

12. Cerwenka A, Lanier LL. Natural killer cells, viruses and cancer. Nat Rev Immunol. 2001;1(1):41-49. doi:10.1038/35095564

13. Roder JC, Pross HF. The biology of the human natural killer cell. J Clin Immunol. 1982;2(4):249-263.
14. Ljunggren HG, Karre K. In search of the 'missing self': MHC molecules and NK cell recognition. Immunol Today. 1990;11 (7):237-244.

15. Leung W. Infusions of allogeneic natural killer cells as cancer therapy. Clin Cancer Res. 2014;20(13):3390-3400. doi:10.1158/ 1078-0432.CCR-13-1766

16. Campbell KS, Purdy AK. Structure/function of human killer cell immunoglobulin-like receptors: lessons from polymorphisms, evolution, crystal structures and mutations. Immunology. 2011;132 (3):315-325. doi:10.1111/j.1365-2567.2010.03398.x

17. Moretta A, Bottino C, Vitale $M$, et al. Activating receptors and coreceptors involved in human natural killer cell-mediated cytolysis. Аnпu Rev Immunol. 2001;19:197-223. doi:10.1146/ annurev.immunol.19.1.197

18. Asmar R, Rizvi NA. Immunotherapy for advanced lung cancer. Cancer J. 2015;21(5):383-391. doi:10.1097/PPO.0000000000000151

19. Chow LQ. Exploring novel immune-related toxicities and endpoints with immune-checkpoint inhibitors in non-small cell lung cancer. Am Soc Clin Oncol Educ Book. 2013. doi:10.1200/EdBook_AM.2013.33.e280

20. Hopewell EL, Zhao W, Fulp WJ, et al. Lung tumor NF-kappaB signaling promotes $\mathrm{T}$ cell-mediated immune surveillance. $J$ Clin Invest. 2013;123(6):2509-2522. doi:10.1172/JCI67250

21. Shi MH, Xing YF, Zhang ZL, Huang JA, Chen YJ. [Effect of soluble PD-L1 released by lung cancer cells in regulating the function of $T$ lymphocytes]. Zhonghua Zhong Liu Za Zhi. 2013;35(2):85-88. doi:10.3760/cma.j.issn.0253-3766.2013.02.002

22. Drake CG, Jaffee E, Pardoll DM. Mechanisms of immune evasion by tumors. Adv Immunol. 2006;90:51-81. doi:10.1016/S0065-2776(06) 90002-9

23. Sakamoto N, Ishikawa T, Kokura S, et al. Phase I clinical trial of autologous NK cell therapy using novel expansion method in patients with advanced digestive cancer. J Transl Med. 2015;13:277. doi:10.1186/s12967-015-0632-8

24. Parkhurst MR, Riley JP, Dudley ME, Rosenberg SA. Adoptive transfer of autologous natural killer cells leads to high levels of circulating natural killer cells but does not mediate tumor regression. Clin Cancer Res. 2011;17(19):6287-6297. doi:10.1158/1078-0432.CCR-11-1347

25. Geller MA, Cooley S, Judson PL, et al. A phase II study of allogeneic natural killer cell therapy to treat patients with recurrent ovarian and breast cancer. Cytotherapy. 2011;13(1):98-107. doi:10.3109/ 14653249.2010.515582

26. Yang YJ, Park JC, Kim HK, Kang JH, Park SY. A trial of autologous ex vivo-expanded NK cell-enriched lymphocytes with docetaxel in patients with advanced non-small cell lung cancer as second- or third-line treatment: phase IIa study. Anticancer Res. 2013;33(5):2115-2122.

27. Iliopoulou EG, Kountourakis P, Karamouzis MV, et al. A phase I trial of adoptive transfer of allogeneic natural killer cells in patients with advanced non-small cell lung cancer. Cancer Immunol Immunother. 2010;59(12):1781-1789. doi:10.1007/s00262-010-0904-3

28. Zhang M, Daniel S, Huang Y, et al. Anti-West Nile virus activity of in vitro expanded human primary natural killer cells. BMC Immunol. 2010;11:3. doi:10.1186/1471-2172-11-3

29. Xie S, Chen J, Zhang M, Wu Z. Allogenic natural killer cell immunotherapy of sizeable ovarian cancer: A case report. Mol Clin Oncol. 2017;6(6):903-906. doi:10.3892/mco.2017.1230

30. Golden-Mason L, Rosen HR. Natural killer cells: multifaceted players with key roles in hepatitis C immunity. Immunol Rev. 2013;255(1):68-81. doi:10.1111/imr.12090

31. Miller AB, Hoogstraten B, Staquet M, Winkler A. Reporting results of cancer treatment. Cancer. 1981;47(1):207-214.

32. Razzaghi H, Quesnel-Crooks S, Sherman R, et al. Leading causes of cancer mortality - caribbean region, 2003-2013. MMWR Morb Mortal Wkly Rep. 2016;65(49):1395-1400. doi:10.15585/mmwr.mm6549a3

33. Torre LA, Bray F, Siegel RL, Ferlay J, Lortet-Tieulent J, Jemal A. Global cancer statistics, 2012. CA Cancer J Clin. 2015;65(2):87-108. doi: $10.3322 /$ caac. 21262 
34. Baas P, Belderbos JS, van den Heuvel M. Chemoradiation therapy in nonsmall cell lung cancer. Curr Opin Oncol. 2011;23(2):140-149. doi:10.1097/CCO.0b013e328341eed6

35. Hsu HS, Huang PI, Chang YL, et al. Cucurbitacin I inhibits tumorigenic ability and enhances radiochemosensitivity in nonsmall cell lung cancer-derived CD133-positive cells. Cancer. 2011;117 (13):2970-2985. doi:10.1002/cncr.25869

36. Sangiolo D, Martinuzzi E, Todorovic M, et al. Alloreactivity and anti-tumor activity segregate within two distinct subsets of cytokine-induced killer (CIK) cells: implications for their infusion across major HLA barriers. Int Immunol. 2008;20(7):841-848. doi:10.1093/ intimm/dxn042

37. Carrega P, Ferlazzo G. Natural killers are made not born: how to exploit NK cells in lung malignancies. Front Immunol. 2017;8:277. doi:10.3389/fimmu.2017.00277

38. Suck G, Branch DR, Keating A. Irradiated KHYG-1 retains cytotoxicity: potential for adoptive immunotherapy with a natural killer cell line. Int J Radiat Biol. 2006;82(5):355-361. doi:10.1080/09553000600649653

39. Goldfarb RH, Ohashi M, Brunson KW, et al. Augmentation of IL-2 activated natural killer cell adoptive immunotherapy with cyclophosphamide. Anticancer Res. 1998;18(3A):1441-1446.

40. Korbelik M, Sun J. Cancer treatment by photodynamic therapy combined with adoptive immunotherapy using genetically altered natural killer cell line. Int J Cancer. 2001;93(2):269-274. doi:10.1002/ijc.1326

41. Farag SS, Fehniger TA, Ruggeri L, Velardi A, Caligiuri MA. Natural killer cell receptors: new biology and insights into the graft-versusleukemia effect. Blood. 2002;100(6):1935-1947. doi:10.1182/blood2002-02-0350

42. Delgado DC, Hank JA, Kolesar J, et al. Genotypes of NK cell KIR receptors, their ligands, and Fcgamma receptors in the response of neuroblastoma patients to Hu14.18-IL2 immunotherapy. Cancer Res. 2010;70(23):9554-9561. doi:10.1158/0008-5472.CAN-10-2211

43. Textor S, Durst M, Jansen L, et al. Activating NK cell receptor ligands are differentially expressed during progression to cervical cancer. Int J Cancer. 2008;123(10):2343-2353. doi:10.1002/ijc.23733

44. Rajalingam R. Human diversity of killer cell immunoglobulin-like receptors and disease. Korean J Hematol. 2011;46(4):216-228. doi:10.5045/kjh.2011.46.4.216

45. Cooley S, Weisdorf DJ, Guethlein LA, et al. Donor selection for natural killer cell receptor genes leads to superior survival after unrelated transplantation for acute myelogenous leukemia. Blood. 2010;116(14):2411-2419. doi:10.1182/blood-2010-05-283051

46. Bachanova V, Cooley S, Defor TE, et al. Clearance of acute myeloid leukemia by haploidentical natural killer cells is improved using IL-2 diphtheria toxin fusion protein. Blood. 2014;123(25):3855-3863. doi:10.1182/blood-2013-10-532531

47. Crouse J, Xu HC, Lang PA, Oxenius A. NK cells regulating T cell responses: mechanisms and outcome. Trends Immunol. 2015;36 (1):49-58. doi:10.1016/j.it.2014.11.001
48. Berg M, Lundqvist A, McCoy P Jr., et al. Clinical-grade ex vivo-expanded human natural killer cells up-regulate activating receptors and death receptor ligands and have enhanced cytolytic activity against tumor cells. Cytotherapy. 2009;11(3):341-355. doi:10.1080/14653240902807034

49. Fujisaki H, Kakuda H, Shimasaki N, et al. Expansion of highly cytotoxic human natural killer cells for cancer cell therapy. Cancer Res. 2009;69(9):4010-4017. doi:10.1158/0008-5472. CAN-08-3712

50. Denman CJ, Senyukov VV, Somanchi SS, et al. Membrane-bound IL-21 promotes sustained ex vivo proliferation of human natural killer cells. PLoS One. 2012;7(1):e30264. doi:10.1371/journal. pone.0030264

51. Lapteva N, Durett AG, Sun J, et al. Large-scale ex vivo expansion and characterization of natural killer cells for clinical applications. Cytotherapy. 2012;14(9):1131-1143. doi:10.3109/14653249.2012. 700767

52. Cho D, Campana D. Expansion and activation of natural killer cells for cancer immunotherapy. Korean J Lab Med. 2009;29(2):89-96. doi:10.3343/kjlm.2009.29.2.89

53. Tonn T, Schwabe D, Klingemann HG, et al. Treatment of patients with advanced cancer with the natural killer cell line NK-92. Cytotherapy. 2013;15(12):1563-1570. doi:10.1016/j.jcyt.2013.06. 017

54. Lin M, Liang SZ, Wang XH, et al. Clinical efficacy of percutaneous cryoablation combined with allogenic NK cell immunotherapy for advanced non-small cell lung cancer. Immunol Res. 2017;65 (4):880-887. doi:10.1007/s12026-017-8927-x

55. Liang S, Lin M, Niu L, et al. Cetuximab combined with natural killer cells therapy: an alternative to chemoradiotherapy for patients with advanced non-small cell lung cancer (NSCLC). Am J Cancer Res. 2018;8(5):879-891.

56. Ishikawa T, Okayama T, Sakamoto N, et al. Phase I clinical trial of adoptive transfer of expanded natural killer cells in combination with IgG1 antibody in patients with gastric or colorectal cancer. Int $J$ Cancer. 2018;142(12):2599-2609. doi:10.1002/ ijc. 31285

57. Barkholt L, Alici E, Conrad R, et al. Safety analysis of ex vivo-expanded NK and NK-like $\mathrm{T}$ cells administered to cancer patients: a phase I clinical study. Immunotherapy. 2009;1 (5):753-764. doi:10.2217/imt.09.47

58. Yang Y, Lim O, Kim TM, et al. Phase I study of random healthy donor-derived allogeneic natural killer cell therapy in patients with malignant lymphoma or advanced solid tumors. Cancer Immunol Res. 2016;4(3):215-224. doi:10.1158/2326-6066.CIR15-0118
OncoTargets and Therapy

\section{Publish your work in this journal}

OncoTargets and Therapy is an international, peer-reviewed, open access journal focusing on the pathological basis of all cancers, potential targets for therapy and treatment protocols employed to improve the management of cancer patients. The journal also focuses on the impact of management programs and new therapeutic agents and protocols on patient perspectives such as quality of life adherence and satisfaction. The manuscript management system is completely online and includes a very quick and fair peer-review system, which is all easy to use. Visit http://www.dovepress.com/ testimonials.php to read real quotes from published authors.

\section{Dovepress}

